\title{
Incisiones verticales en SARPE
}

\author{
Vertical incisions in SARPE
}

\author{
J. Gonzalez Lagunas, J.A. Hueto Madrid, G. Raspall Martín
}

Resumen: La expansión rápida de paladar asistida quirúrgicamente (SARPE) es una de las opciones terapeuticas de los transtornos transversales del maxilar superior. Presentamos nuestra experiencia inicial con una variante técnica consistente en una corticotomía de la pared lateral del maxilar combinada con una osteotomía palatina media transincisal, y efectuadas a través de tres pequeñas incisiones verticales.

Palabras clave: Osteotomía maxilar; Expansion paladar.

Recibido: 11 de noviembre 2004

Aceptado: 21 de marzo 2005

\section{Introducción}

La expansión rápida de paladar asistida quirúrgicamente (SARPE) es, junto con la disyunción ortopédica del maxilar y la osteotomía de Lefort I segmentada, una de las técnicas disponibles para corregir los defectos transversales del maxilar superior. Los problemas transversales de maxilar superior afectan a un porcentaje de la población de un 9,4\%, aunque en el grupo de pacientes que solicitan tratamiento de una deformidad dentofacial puede llegar hasta a un 30\%. ${ }^{1,2}$

Presentamos una modificación técnica del procedimiento, que minimiza el trauma quirúrgico con el fín de reducir la morbilidad postoperatoria.

Servicio de Cirugía Oral y Maxilofacial

Hospital Universitario Vall de Hebrón, Barcelona, España

Correspondencia:

Dr. Javier Gonzalez Lagunas

Gnation

Casanova 101 Pral-1ำ

08011 Barcelona, España

\begin{abstract}
Surgically assisted rapid palatal expansion (SARPE) is one of the therapeutic options for the correction of transverse maxillary collapse. We present our initial experience with a technique consisting in a lateral corticotomy of the maxilla plus a transincisal midpalatal osteotomy, both performed through minimal vertical incisions.
\end{abstract}

Key words: Palatal expansion; Maxillary osteotomy.

\section{Introduction}

Surgically assisted rapid palatal expansion (SARPE) is, together with orthopedic disjunction of the maxilla and the segmented Lefort I osteotomy, one of the techniques that are available for correcting transverse defects of the upper maxilla. Transverse problems of the upper maxilla affect $9.4 \%$ of the population, although in the group of patients requesting treatment for dento-facial deformities this can reach 30\%.1,2

We present a technical modification of the procedure that minimizes surgical trauma and is aimed at reducing postoperative morbidity.

\section{Technique}

We prefer operating the patient with a precemented Hyraxtype disjunction appliance. Following local anesthesia infiltration, two vertical vestibular incisions are made with a Colorado tip between the canine and the first premolar (Fig. 1). The outer face of the maxilla is tunneled carefully between the 


\section{Técnica}

Preferimos intervenir al paciente con un disyuntor tipo Hyrax precementado. Tras la infiltración con anestesia local, se realizan dos incisiones vestibulares verticales con punta Colorado entre el canino y el primer premolar (Fig. 1). Se tuneliza cuidadosamente la cara externa del maxilar entre la escotadura nasal y el arbotante zigomático-maxilar, con una minima extensión vertical. Se introduce el separador mandibular de Obwegeser que se apoya sobre la tuberosidad. Con sierra oscilante o fresa de fisura se efectúa la línea de osteotomía, asegurando con el escoplo la desaparición de toda resistencia, especialmente en el arbotante cigomático-maxilar (Fig. 2). La osteotomía del rafe palatino medio se efectúa de forma transmucosa introduciendo un escoplo en el espacio interincisal. El escoplo se introduce suavemente hasta que el cirujano palpa su salida por palatino, pero sin perforar su fibromucosa. Se continúa la osteotomía hasta el sector posterior del paladar duro, siempre controlando su posición por debajo de la mucosa palatina.

Una vez efectuadas las osteotomías, se procede a la activación del disyuntor, comprobando la separación interincisal.

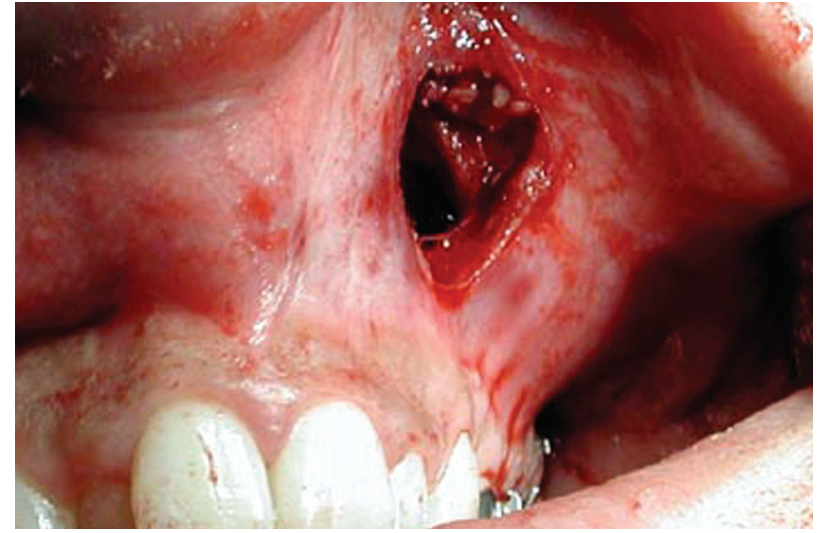

Figura 1. Incisión vertical para acceder a la corticotomía lateral. Figure 1. Vertical incision providing access for the lateral wall corticotomy.

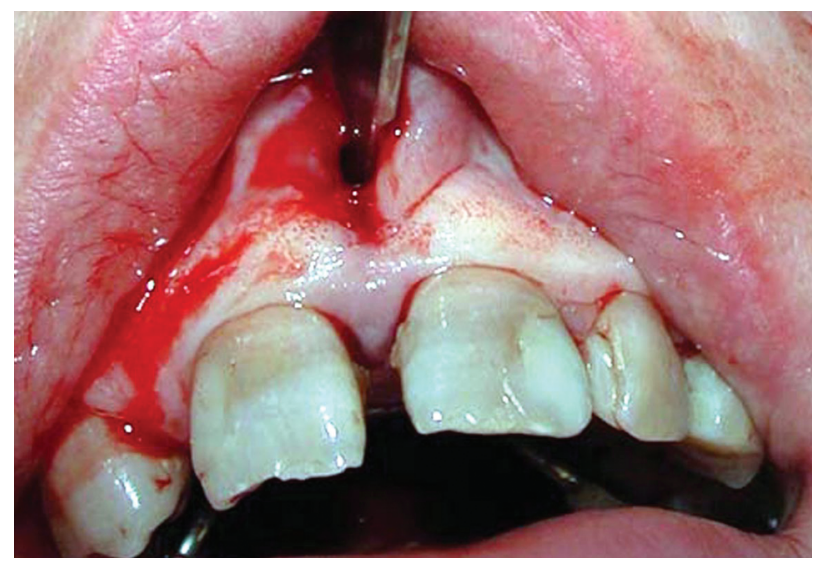

Figura 2. Osteotomía transincisal. Figure 2. Transincisal osteotomy. nasal notch and the zygomatic-maxillary buttress, with a minimum vertical extension. The Obwegeser separator is introduced and rested on the tuberosity. With an oscillating saw or a fissure burr the osteotomy line is made, making sure with a chisel that there is no resistance, especially by the zygomatic-maxillary buttress (Fig. 2). The osteotomy of the median palatine raphe is made in a transmucosal manner by introducing the chisel into the interincisal space. The chisel is introduced gently until the surgeon can feel it coming out through the palate, but without perforating its fibrous membrane. The osteotomy is continued to the back of the hard palate, while controlling at the same time its position underneath the palatine mucosa.

Once the osteotomies have been carried out, the disjunction appliance is activated, while verifying the interincisal separation.

\section{Resultados}

Esta técnica se ha aplicado de forma consecutiva en 4 pacientes tributarios de SARPE por colapso maxilar transversal. Los datos demográficos de los pacientes incluyen 2 varones y dos mujeres con edades comprendidas entre los 24 y los 39 años. En uno de los casos se trató de un procedimiento aislado, en otro ya se ha practicado una cirugía bimaxilar, y los otros dos pacientes están pendientes de tratamiento definitivo con otro tipo de osteotomías.

Con este procedimiento no se ha observado una mayor incidencia complicaciones intraoperatorias ni postoperatorias que con la técnica utilizada anteriormente. Se ha constatado una mejor respuesta de los tejidos blandos y un menor edema posoperatorio.

\section{Discusión}

La experiencia de los autores con la SARPE ya ha sido recogida en un artículo previo. ${ }^{3}$ En los últimos casos y con el fín de disminuir las
Results

This technique has been applied consecutively in four patients requiring SARPE due to transverse maxillary collapse. The demographic data of the patients included two males and two females between the ages of 24 and 39. In one of the cases this was an isolated procedure, in another bimaxillary surgery has since been carried out, and the other two patients are awaiting definitive treatment with another type of osteotomy.

With this procedure a greater incidence of complications has not been observed, either intraoperatively or postoperatively, than with the technique used previously. A better response has been noted in soft tissues with better postoperative edema.

\section{Discussion}

The experience of these authors with SARPE has been included in a previous article. ${ }^{3}$ In these last cases, and with 
molestias del paciente se han introducido modificaciones técnicas dirigidas a minimizar el trauma quirúrgico. Una revisión de la literatura permite constatar las numerosas modificaciones técnicas de SARPE que existen, y también que no parecen existir diferencias significativas entre ellas en lo que se refiere a estabilidad. Brown, en 1938 describió una osteotomía palatina media aislada. ${ }^{4}$ Posteriormente, se introdujeron las corticomías laterales para tratar el colpaso maxilar 5,6 y Lines, en 1975 combinó por vez primera la osteotomía palatina media con las corticotomías laterales. ${ }^{7}$ Bell y Epker posteriormente aplicaron el Lefort I completo pero sin «down-fracture» o sin separación de la pared nasal lateral.2, 8-10 En la década de los 80 se aplicaron técnicas menos agresivas que se podían realizar bajo sedación: corticotomía lateral y osteotomía interincisal, ${ }^{11}$ corticotomía lateral y palatina media a traves de una incisión palatina paramedial, ${ }^{12} \mathrm{o}$ transpalatina, ${ }^{13,14} \mathrm{u}$ osteotomía palatina a través de la escotadura piriforme. ${ }^{15}$ No existen evidencias clínica sobre la necesidad de practicar un osteotomía ptérigomaxilar, siendo solamente recomendada en un trabajo experimental sobre modelos. ${ }^{16}$

Esta revisión de la literatura confirma que no existen diferencias clínicas significativas en cuanto a resultados y estabilidad, independientemente de la técnica empleada. Es posible así experimentar con modificaciones técnicas que faciliten el procedimiento quirúrgico y que disminuyan las molestias subjetivas del paciente. Con las incisiones verticales se accede fácilmente al límite anterior y posterior de la corticotomía lateral. Además al no incidir la mucosa en sentido anteroposterior, en aquellos pacientes que precisen una osteotomía de Lefort 1 convencional, se facilita la elevación de los colgajos mucoperiósticos.

\section{Conclusiones}

Presentamos una modificación técnica consistente en la práctica de la SARPE a través de tres pequeñas incisiones verticales y consistente solamente en corticotomía lateral y en osteotomía palatina transincisal. La técnica minimiza el trauma quirúrgico, y no se acompaña de complicaciones significativas.

\section{Bibliografía}

1. Proffit WR, Philips C, Dann CIV. Who seeks surgical orthodontic treatment. Int I Adult Orthod Orthognat Surg 1990;3:153-60.

2. Betts NJ, Vanarsdale RL, Barber HD. Diagnosis and treatment of transverse maxillary deficiency. Int J Adult Orthod Orthogn Surg 1995;10:75-96.

3. Gonzalez J, Hueto J.A. Raspall G. Expansión rápida de paladar asistida quirúrgicamente. RCOE.

4. Brown GVI. The Surgery of Oral and Facial Diseases and Malformations; ed 4, Londres: Kimpton 1938;p.p.507.

5. Koele H. Surgical operations on the alveolar ridge to correct occlusal abnormalities. Oral Surg 1959;12:515-29.

6. Converse JM, Horowitz SL. The surgical orthodontic approach to treatment of dentofacial deformities. Am J Orthod 1969;55:217-43.

7. Lines PA. Adult rapid maxillary expansion with corticotomy. Am / Orthod 1975;67:44-56. the aim of reducing the discomfort for patients, technical modifications have been introduced for minimizing surgical trauma. A revision of the literature permits confirming the existence of numerous technical SARPE modifications and, with regard to stability, there do not appear to be any significant differences. Brown in 1938 described an isolated midpalatal osteotomy. ${ }^{4}$ Later, lateral wall corticotomies were introduced in order to treat maxillary collapse, 5,6 and in 1975 Lines combined the midpalatal osteotomy for the first time with lateral wall corticotomies.' Bell and Epker later applied the complete Lefort I osteotomy but without the down-fracture, or without separating the lateral nasal wall.2,8-10 In the decade of the 80s, less aggressive techniques were applied that could be carried out under sedation: lateral wall corticotomies with interincisal osteotomies, 11 lateral wall corticotomies with midpalatal osteotomies through a paramedial palatal incision ${ }^{12}$ or a transpalatal incision, 13,14 or palatal osteotomies through the pyriform aperture. ${ }^{15}$ There is no clinical evidence as to the need for carrying out pterygomaxilary osteotomies, and they have only been recommended in an experimental study on models. ${ }^{16}$

Our revision of the literature confirms that there are no significant clinical differences as to results and stability, independent of the technique used. It is therefore possible to experiment with modified techniques so that surgical procedures are made easier and the subjective discomfort of the patient is reduced. In a lateral wall corticotomy, the anterior and posterior ends are easily accessed with vertical incisions. In addition, for those patients requiring a conventional Lefort 1 osteotomy, raising mucoperiosteal flaps is made easier as the mucosa is not cut in an anteroposterior sense.

\section{Conclusions}

We present a technical modification that consists in carrying out SARPE through three small vertical incisions. It consists only in a lateral corticotomy and a transincisal palatal osteotomy. The technique minimizes surgical trauma and there are no significant complications. 
8. Bell WH, Epker BN. Surgical orthodontic expansion of the maxilla. Am J Orthod 1976;70:517-28.

9. Turvey TA. Maxillary expansion. A surgical technique based on surgical orthodontic treatment objectives and anatomic considerations. I Maxillofac Surg 1985; 13:51-8.

10. Mossaz CF, Byloff FK, Richter M. Unilateral and bilateral corticotomies for correction of maxillary transverse discrepancies. Eur / Orthod 1992; 14:110-6.

11. Bays RA, Greco JM. Surgically assisted rapid palatal expansion: an outpatient technique with long term stability. I Oral Maxillofac Surg 1992;50:110-3.
12. Racey G. Surgically assisted rapid palatal expansion: an outpatient technique with long term stability: (discusión). J Oral Maxillofac Surg 1992;50:114-5.

13. Pogrel MA, Kaban LB, Vangervik K. Surgically assisted rapid maxillary expansion in adults. Int I Adult Orthod Orthognath Surg 1992;7:37-41.

14. Kraut RA. Surgically assisted rapid maxillary expansion by opening the midpalatal suture. J Oral Maxillofac Surg 1984;42:651-5.

15. Zahl C, Gerlach KL. Fine edge osteotome for submucous palatal osteotomy. Br J Oral maxilllofac Surg 2004;42:49-50.

16. Shetty V, Mendoza J, Caputo A, Chaconas SJ. Biomechanical rationale for surgical-orthodontic expansion of the adult maxilla. / Oral MaxiIlofac Surg 1994;52:742-9. 